\title{
Substitution of rumen degradable nitrogen with urea in sheep fed low quality
}

\section{Eragrostis curvula hay}

\author{
Herman Mynhardt, Willem Adriaan Van Niekerk*, Lourens Johannes Erasmus, Abubeker Hassen, Roelf Johannes Coertze
}

University of Pretoria - Dept. of Animal and Wildlife

Sciences, Private Bag x20 - 0028 - Pretoria - South

Africa.

${ }^{*}$ Corresponding author <willem.vanniekerk@up.ac.za>

Edited by: Jhones 0. Sarturi/Paulo Cesar Sentelhas

Received July 23, 2015

Accepted February 19, 2016

\begin{abstract}
The aim of the present study was to determine whether sunflower meal (SFM), a highly rumen degradable protein (RDP) source, can be substituted with non-protein nitrogen (NPN, urea) without impacting negatively on intake, digestibility, rumen fermentation and microbial nitrogen (N) synthesis (MNS) in wethers consuming low quality Eragrostis curvula hay. Five wethers were fed ad libitum, low quality hay and supplemented twice-daily in equal proportions, via the rumen cannulae, one of five iso-nitrogenous and iso-energetic supplements in a $5 \times 5$ Latin square design experiment. The supplements differed in the ratios of rumen degradable $\mathrm{N}$ (RDN) supplied by either SFM and/or urea and is presented as percentage of RDN supplied by urea: T0 (100\% SFM, 0 \% urea); T15 (85 \% SFM, $15 \%$ urea); T30 (70 \% SFM, $30 \%$ urea); T45 ( $55 \%$ SFM, $45 \%$ urea) and T60 (40 \% SFM, $60 \%$ urea). Forage intake and total tract dry matter (DM) digestibility did not differ; however, higher forage neutral detergent fiber (NDF) digestibilities were observed in the sheep supplemented with the higher urea-treatments (T45 and T60) compared to T15. Neither rumen $\mathrm{pH}$ nor total rumen volatile fatty acid (VFA) concentraions differed. The mean rumen ammonia nitrogen (RAN) concentration of the sheep supplemented with T60 was higher than T30 (9.35 $\mathrm{mg} \mathrm{dL}^{-1}$ vs. $7.41 \mathrm{mg} \mathrm{dL}^{-1}$ ); however, no differences were observed in MNS or efficiency of MNS among treatments. Results suggest that up to $60 \%$ of RDN supplied by SFM can be substituted with urea, without affecting intake, digestibility or MNS in wethers fed a low quality tropical hay.

Keywords: low quality roughage, rumen ammonia, microbial synthesis
\end{abstract}

\section{Introduction}

Animal production in the tropics is severely limited by nutritional constraints, with animals losing up to $30 \%$ of their total body weight during the dry season (Almeida et al., 2006). Typically, low quality tropical roughages contain less than $6 \%$ crude protein (CP) (Detmann et al., 2009; Leng, 1990), which is insufficient to meet the ruminants' maintenance requirements (NRC, 2007). Nutritional deficiencies during these periods can be overcome by nitrogen $(\mathrm{N})$ and/or protein supplementation (Ferrell et al., 1999; Köster et al., 1996).

Urea is commonly used as a rumen degradable nitrogen (RDN) supplement because it is more cost effective per unit of RDN than true protein. However, results from supplementation studies on the use of non-protein $\mathrm{N}$ (NPN) versus true protein as sources of RDP are contradictory and inconclusive (Köster et al., 1997; Kozloski et al., 2014). Russel (1984) further suggested that cellulolytic bacteria only need rumen ammonia nitrogen (RAN) for growth while Arroquy et al. (2004) stated that rumen branched-chain volatile fatty acids, derived from the deamination of amino acids, are essential to the production of fiber reducing bacteria.

A possible reason for the inconsistent results observed in supplementation studies is the differences in nutrient bioavailability between low quality tropical and temperate forages (Bohnert et al., 2011). Low quality temperate grasses contain higher levels of water soluble carbohydrates (WSC) and RDN levels compared to tropical grasses (Bohnert et al., 2011). In addition, recent studies suggest that microbial needs to optimise forage utilisation and microbial $\mathrm{N}$ synthesis (MNS) differ between ruminants consuming either low quality tropical or temperate grasses (Detmann et al., 2009; Kanjanapruthipong and Leng, 1998). These factors suggest that ruminants consuming low quality tropical grasses might have different supplementation requirements to optimise rumen fermentation compared to ruminants consuming low quality temperate grasses.

Most supplementation studies on forage fed ruminants, however, have been conducted on ruminants consuming low quality temperate forages (Leng, 1990). Information on the supplementation of ruminants consuming low quality tropical forages therefore is scarce and inconclusive. The aim of the study was to investigate whether the form of RDN supplemented either as a true protein or as an NPN source will influence forage intake, digestibility and MNS in sheep fed a basal diet of low quality tropical roughages.

\section{Materials and Methods}

The Animal and Ethical Committee of the University of Pretoria, South Africa approved the protocol. Five rumen-cannulated Merino wethers $(58 \pm 1.1 \mathrm{~kg}$ body weight) were fed ad libitum a low quality [3\% CP; $87 \%$ neutral detergente fiber (NDF); $50 \%$ acid detergent fiber $(\mathrm{ADF})$, dry matter (DM)-basis] Eragrostis curvula hay. The sheep were assigned to one of five treatments in a $5 \times 5$ 
Latin square design experiment. The supplements, containing sunflower meal (SFM), urea, starch and a mineral supplement were supplemented in equal proportions, twice-daily at $08 \mathrm{~h} 00$ and $16 \mathrm{~h} 00$, and were introduced into the rumen via rumen cannulae. The supplements differed in the ratio of RDN supplied by SFM and urea and were assigned T0; T15; T30; T45 and T60 respectively, where the acronyms indicated that $0 \%, 15 \%, 30 \%, 45 \%$ and 60 $\%$ of the RDN fraction of SFM was substituted with urea respectively. Starch was added in incremental quantities as SFM was substituted by urea to keep the supplements iso-energetic. In addition, a mineral premix and additional sulphur were added to each supplement to meet the maintenance requirements of the wethers (NRC, 2007). The ingredients used in the formulation of each supplement are given in Table 1.

Each experimental period consisted of 22 days, with a 10 day adaptation period followed by a 5 day sampling period, a 3 day in sacco incubation period and a 4 day period in which two sets of rumen fluid samples were collected for RAN and volatile fatty acid (VFA) analyses. During the adaptation period, the wethers remained in an outside pen and were group-fed the low quality $E$. curvula hay. Supplements (treatments) were individually introduced at $08 \mathrm{~h} 00$ and $16 \mathrm{~h} 00$ directly into the rumen through the rumen cannulae. On day 8 of the adaptation period, the wethers were allocated to separate metabolic crates where fecal bags were fitted.

Feed intake and fecal and urine output were recorded daily, sampled and pooled over the 5 day experimental period within each treatment to estimate apparent total tract digestibility. Urine was gathered from urine pans into urine bottles preserved with $5 \mathrm{~mL} \mathrm{H}_{2} \mathrm{SO}_{4}(50 \% \mathrm{v}$ : v). The $\mathrm{pH}$ of the urine was monitored (every 4-6 h) and adjusted to a $\mathrm{pH} 3$ using $\mathrm{H}_{2} \mathrm{SO}_{4}$ if required. Daily urine volumes were measured and diluted to $4000 \mathrm{~mL}$. From this diluted volume, $50 \mathrm{~mL}$ sub samples were taken, pooled

Table 1 - Total daily ingredient supplementation and nutrient composition of the five different supplementation treatments.

\begin{tabular}{|c|c|c|c|c|c|}
\hline Treatments* $^{*}$ & T0 & T15 & T30 & T45 & T60 \\
\hline \multicolumn{6}{|l|}{ Ingredients (g DM d-1) } \\
\hline Sunflower meal & 130 & 111 & 91 & 72 & 53 \\
\hline Urea & 0 & 2.4 & 4.8 & 7.2 & 9.5 \\
\hline Starch & 0 & 12.6 & 25.1 & 37.7 & 50.3 \\
\hline Mineral pre-mix * * & 24.2 & 24.2 & 24.2 & 24.2 & 24.2 \\
\hline Sulphur & 1.8 & 1.8 & 1.8 & 1.8 & 1.8 \\
\hline \multicolumn{6}{|c|}{ Nutrient intake of supplements (as supplied) } \\
\hline Metabolisable Energy (MJ ME $\mathrm{d}^{-1}$ ) & 1.29 & & & & \\
\hline Crude Protein ( $\left.\mathrm{g} \mathrm{CP} \mathrm{d}^{-1}\right)$ & 43.79 & & & & \\
\hline
\end{tabular}

${ }^{*}$ Treatments: T0, T15, T30, T45 and T60 indicate that 0\%, $15 \%, 30 \%, 45$ $\%$ and $60 \%$ of the supplemental rumen degradable nitrogen fraction of the sunflower meal was substituted with urea respectively. Total daily supplements were supplemented twice daily in equal proportions at $08 \mathrm{~h} 00$ and $16 \mathrm{h00}$ into the rumen. ${ }^{* *}$ Mineral composition of the premix: Macro minerals $\left(\mathrm{g} \mathrm{kg}^{-1} \mathrm{DM}\right)$ : K (230); Ca (83); P (63); Mg (46); Na (29); Cl (26); Trace minerals (mg kg-1 DM): Co (4.58); Cu (166.53); I (33.31); Fe (333.06); Mn (726.48); Se (1.67) and $\mathrm{Zn}(1248.96)$ over the collection period and frozen at $-20^{\circ} \mathrm{C}$ for purine derivative (PD) analysis. The PD analyses were used for the estimation of microbial nitrogen synthesised (MNS) as described by Chen and Gomes (1992).

Rumen fluid was collected at $12 \mathrm{~h}$ intervals for 4 days with samples taken from four predetermined locations within the rumen (top left, centre, bottom left and centre). Every day, there was a $3 \mathrm{~h}$ interval between sample collection times. Thus, samples were taken at $03 \mathrm{~h} 00$, 06h00, 09h00, 12h00, 15h00, 18h00, 21h00 and 24h00. Rumen fluid $\mathrm{pH}$ was measured immediately after each collection period. The samples were pooled within treatment and collection period. Five $\mathrm{mL} \mathrm{H}_{2} \mathrm{SO}_{4}(10 \% \mathrm{v}$ : v) and $4 \mathrm{~mL} \mathrm{H}_{2} \mathrm{PO}_{4}(25 \% \mathrm{v}$ : v) were added to $30 \mathrm{~mL}$ and 25 $\mathrm{mL}$ rumen samples respectively for RAN analyses (Broderick and Kang, 1980) and VFA concentrations (Vanzant and Cochran, 1994). The samples were frozen at $-20^{\circ} \mathrm{C}$ until analysis was initiated.

Feed and fecal samples were ground using a Wiley mill to pass through a $1 \mathrm{~mm}$ screen. Hay, orts and fecal samples were dried for $24 \mathrm{~h}$ at $105^{\circ} \mathrm{C}$ in a forced-air oven for DM determination (AOAC, 2000, Method 934.01) after which it was combusted for $8 \mathrm{~h}$ at $450{ }^{\circ} \mathrm{C}$ in a muffle furnace to determine organic matter (OM) (AOAC, 2000, Method 942.05). The $\mathrm{N}$ content of hay, faeces and urine was determined by the kjeldahl methods (AOAC, 2000). All hay, orts and fecal samples were analysed for NDF and ADF with the ANKOM-Fiber Analyzer (Goering and Van Soest, 1988). In vitro organic matter digestibility (IVOMD) was determined using the Tilley and Terry method (Tilley and Terry, 1963) as modified by Engels and Van der Merwe (1967). Additional $\mathrm{N}$ in the form of urea $(2 \mathrm{~mL}$ of an $8.68 \mathrm{~g}$ urea $\mathrm{dL}^{-1}$ solution) was added to each $30 \mathrm{~mL}$ test tube containing rumen fluid and artificial saliva, in order to simulate $\mathrm{N}$ recycling in the wethers and to increase the IVOMD repeatability of the roughages.

In sacco rumen incubations were conducted to determine the forage and SFM effective degradability (ED) in the rumen (Ørskov and McDonald, 1979). Approximately $5 \mathrm{~g}$ hay (DM; ground through a $2 \mathrm{~mm}$ screen) was weighed into R510 ANKOM bags $(8 \times 5 \mathrm{~cm}$ nylon bags, pore size of $50 \mu \mathrm{m})$. Duplicate bags were suspended in an opaque nylon stocking into the rumen (Cruywagen, 2006) and retrieved at $2,4,8,12,24,48$ and $72 \mathrm{~h}$. Following incubation, all bags, as well as a 0 hour control bag, were washed under running tap water until the water, obtained by gently squeezing the bags, was clear. The bags and contents were dried at $60{ }^{\circ} \mathrm{C}$ in a forced-draught oven for 48 $\mathrm{h}$ before NDF analyses.

\section{Calculations}

The model, $\mathrm{y}=0.84 \mathrm{x}+\left(0.15 \mathrm{BW}^{0.75} \mathrm{e}^{-0.25 \mathrm{x}}\right)$ was used to calculate daily MNS from PD analysed from urine (Chen and Gomes, 1992). In the model, y represented total PD found in the daily urine, while $\mathrm{x}$ represented total MNS. The model corrected for the contribution of endogenous purine derivatives, which are represented by the component within the parentheses. The calculation of 
$\mathrm{x}$ from $\mathrm{y}$ based on the equation was made by means of Newton's iteration process (Chen and Gomes, 1992).

The nonlinear model: $\mathrm{y}=\mathrm{a}+\mathrm{b}\left(1-\mathrm{e}^{-\mathrm{ct}}\right)$ was used for the in sacco analyses as described by Ørskov and McDonald (1979). The disappearance values at different time intervals were used to calculate the degradation constants of NDF, where $\mathrm{y}=$ the disappearance of NDF at time $t ; a$ is the washing loss (rapidly soluble fraction); $\mathrm{b}$ the slowly degradable NDF fraction, and $\mathrm{c}$ the rate $\left(\mathrm{h}^{-1}\right)$ of degradation of fraction $\mathrm{b}$. All fractions were expressed on a $\mathrm{g} \mathrm{kg}^{-1} \mathrm{DM}$ basis. The degradation constants were used to estimate potential degradability (PD) and effective degradability (ED) where $\mathrm{PD}=\mathrm{a}+\mathrm{b}$ and $\mathrm{ED}$ $=\mathrm{a}+[\mathrm{bc} /(\mathrm{k}+\mathrm{c})]$. In this model, $\mathrm{k}$ is the passage rate from the rumen, assumed to be $0.02 \mathrm{~h}^{-1}$ for ruminants consuming low quality forages.

\section{Statistical analysis}

Data were subjected to an analysis of variance (ANOVA) using the Proc GLM procedure from SAS (Statistical Analysis System, 2006) with a model appropriate for a $5 \times 5$ Latin square. Variables in the model were animal, treatment and period. The data were tested for linear, quadratic and cubic effects for increasing levels of urea. The repeated measures analysis of variance function using GLM model were used for repeated period measurements. Significance was declared at $p<0.05$ using Fischers test (Samuels, 1989).

\section{Results and Discussion}

The high NDF and ADF concentrations of the $E$. curvula are indicative of the poor quality of the hay (Table 1). In addition, the $\mathrm{CP}$ concentration of the hay was well below the suggested level of the $6 \%$ necessary to meet the maintenance requirements of the wethers (NRC, 2007). This low CP percentage of the hay emphasized the necessity of nitrogenous supplementation for ruminants consuming low quality tropical forages (Detmann et al., 2009; Kanjanapruthipong and Leng, 1998; Köster et al., 1996, 1997). Due to the low CP concentration of the hay, it was decided not to have a negative control treatment as the potential risk of rumen stasis would have been too high. Similarly, it was decided not to replace the complete RDN fraction of the SFM with urea (100 \% NPN treatment) as the quantity of urea necessary to replace the total RDN fraction of the SFM would have been more than $16 \mathrm{~g}$ urea wether ${ }^{-1} \mathrm{~d}^{-1}$, which, at approximately $1.6 \%$ of the DM intake, would have been well above the $1 \% \mathrm{DM}$ recommendations for wethers (Edjtehadi et al., 1978). In addition, Bohnert et al. (2011) showed that the quantity and availability of the WSC fraction of tropical grasses is significantly lower compared to temperate grasses. This lower WSC quantity and availability in tropical grasses had the potential to reduce the utilisation of RAN by the rumen microorganisms even more in the tropical forage fed ruminant (Leng, 1990). As a result, it was decided to substitute only up to $60 \%$ of the RDN fraction of SFM with urea in order to limit the possibility of rumen $\mathrm{NH}_{3}-\mathrm{N}$ toxicity in the wethers.

No linear, cubic or quadratic effects were observed for any parameter as the level of urea substituting the RDN fraction of the SFM to the wethers, was increased. As such, only the individual differences among treatments within each observation are discussed.

On a DM basis, the SFM contained $42 \% \mathrm{CP}, 38 \%$ NDF and $29 \%$ ADF. The RDP fraction of the SFM, based on a rumen outflow of $2 \% \mathrm{~h}^{-1}$ contained $36 \% \mathrm{RDP}$ (or $85 \%$ of the total CP fraction). As the different treatments were formulated to substitute the RDP fraction of SFM with urea, total CP supplied to the wethers differed between the various supplemental treatments $(54.2,53.0$, $52.5,52.0$ and $51.5 \mathrm{~g} \mathrm{CP} \mathrm{d}^{-1}$ respectively for T0, T15, T30, $\mathrm{T} 45$ and T60). However, the calculated RDP supplied by the supplements was similar with a mean intake of 46.9 g CP wether ${ }^{-1} \mathrm{~d}^{-1}$.

Forage intake and digestibility did not differ between treatments $(p>0.05$; Table 2$)$. This observation is in contrast with the studies of Köster et al. (1997) where it was observed that incremental substitutions of RDN with NPN sources decreased feed intake and digestibil-

Table 2 - Daily dry matter (DM) intake, diet digestibility and in sacco ruminal neutral detergent fiber (NDF) degradability of Eragrostis curvula hay in sheep as affected by the substitution of sunflower meal (SFM) with urea.

\begin{tabular}{lrrrrrr}
\hline \multirow{2}{*}{ Parameters * } & \multicolumn{7}{c}{ Treatments* } \\
\cline { 2 - 7 } Intake (g d ${ }^{-1}$ ) & \multicolumn{1}{c}{ T15 } & \multicolumn{1}{c}{ T30 } & \multicolumn{1}{c}{ T45 } & T60 & SEM $^{* *}$ \\
$\quad$ Forage DMl & 1067 & 1008 & 1147 & 1066 & 1048 & 73.5 \\
Total DMl & 1223 & 1260 & 1294 & 1209 & 1187 & 51.9 \\
DOMl & 687 & 698 & 718 & 703 & 667 & 58.9 \\
NDF & 841 & 789 & 885 & 858 & 838 & 55.9 \\
& & & & & & \\
NDF (g kg-1 BW) & 14.6 & 13.8 & 15.2 & 14.6 & 14.3 & 0.90 \\
& & & & & & \\
Digestibility (g 100 g ${ }^{-1}$ DM) & & & & & \\
DM & 55 & 51 & 55 & 57 & 56 & 2.8 \\
OM & 59 & 55 & 58 & 62 & 61 & 2.6 \\
NDF & 60 & 57 & 59 & 65 & 63 & 2.2 \\
Forage NDF degradability & & & & & \\
a (\%) & 6.2 & 10.0 & 8.9 & 8.9 & 7.4 & 1.6 \\
b (\%) & 76 & 57 & 58 & 58 & 70 & 8.4 \\
c (\% h-1) & 2.0 & 2.0 & 1.5 & 1.8 & 1.7 & 0.04 \\
PD (\%) & 83 & 67 & 67 & 67 & 77 & 7.9 \\
ED (\%) & 35 & 33 & 31 & 33 & 33 & 0.7 \\
\hline
\end{tabular}

No linear, cubic or quadratic effects were observed among treatments in any parameter as urea substituted the SFM supplemented to the wethers. Means within a row did not differ ( $p>0.05$ ). ${ }^{*}$ T0 (100\% SFM, $0 \%$ urea); T15 (85 \% SFM, $15 \%$ urea); T30 (70\% SFM, $30 \%$ urea); T45 (55 \% SFM, $45 \%$ urea) and T60 (40\% SFM, $60 \%$ urea). ${ }^{*}$ DMI = Dry Matter Intake; $\mathrm{DOMI}=$ Digestible Organic Matter Intake; NDF = Neutral Detergent Fiber; $\mathrm{BW}=$ Body Weight; DMD = Dry Matter Digestibility; OMD = Organic Matter Digestibility; NDFD = Neutral Detergent Fiber Digestibility; $a=$ soluble fraction; $b=$ potential degradable fraction; $c=$ rate of degradation; $P D=$ Potential Degradability; ED = Effective Degradability; ${ }^{* *}$ SEM = Standard error of the mean. 
ity in cattle consuming low quality Prairie (tropical) hay. In general it is acknowledged that supplemental starch decreases forage intake and digestibility of low quality forages (Caton and Dhuyvetter, 1997), probably through a reduction of rumen $\mathrm{pH}$ (Mould and Ørskov, 1983). In the study reported by Köster et al. (1997), incremental amounts of starch were added to the supplements as the level of urea was increased to keep the supplements isoenergetic. This increase in starch concentration could have resulted in a decrease in forage intake and digestibility in that study. While starch was added in the present study in a similar manner compared to the study of Köster et al. (1997), the level of $\mathrm{N}$ intake in all treatments was according to NRC (2007) standards meeting the maintenance requirements of the wethers. None of the wethers during each experimental treatment, therefore, were protein deficient. Caton and Dhuyvetter (1997) in a review suggested that the negative effects of energy supplementation on forage intake and/or digestibility is protein dependant where forage-fed ruminants can tolerate greater levels of starch intake if the low quality forage diets are supplemented with $\mathrm{N}$ supplements.

In the present study, the highest daily starch supplementation (T60 treatment) was $50.3 \mathrm{~g}$ (DM-basis; Table 1), representing less than $5 \%$ of the daily DMI (Table 2). This concentration is below the $20 \%$ starch level considered to be detrimental to forage intake in ruminants fed forages supplemented with protein (Gomes et al., 1994; Henning et al., 1980). In addition, the starch was supplemented twice daily in the present study, together with urea, in equal proportions and was introduced into the rumen. Therefore, only half of the daily starch and urea amounts were supplemented during each supplementation period which could have decreased the potential negative effects of starch on the rumen milieu. This was then observed as the rumen $\mathrm{pH}$ in all time-periods and treatments was above 6.2 (Table 3) suggesting that cellulolytic fermentation was not inhibited in the wethers (Mould and Ørskov, 1983). As a result, forage intake and digestibility were similar among treatments (Table 2).

Köster et al. (1996) suggested that DMI is maximized in cattle when NDF intake is $12.5 \mathrm{~g} \mathrm{NDF} \mathrm{kg}^{-1} \mathrm{BW}^{-1} \mathrm{~d}^{-1}$. The authors further suggested that intake responses to $\mathrm{CP}$ or $\mathrm{N}$ supplementation could be expected only if NDF intake of low quality forages is below this value. Ferrell et al. (1999) and Bohnert et al. (2002) observed slightly higher corresponding values (13.0 and $14.8 \mathrm{~g} \mathrm{NDF} \mathrm{kg}^{-1} \mathrm{BW}^{-1}$ $\mathrm{d}^{-1}$ respectively) in lambs consuming low quality forages and supplemented with protein sources. In this trial, NDF intake did not differ between treatments, ranging from $13.8 \mathrm{~g} \mathrm{NDF} \mathrm{kg}^{-1} \mathrm{BW}^{-1} \mathrm{~d}^{-1}$ for the T15 treatment to $15.2 \mathrm{~g}$ NDF kg ${ }^{-1} \mathrm{BW}^{-1} \mathrm{~d}^{-1}$ for the T30 treatment (Table 2). These NDF intakes therefore suggest that protein supplementation was sufficient to maximise forage intake among treatments and that additional $\mathrm{N}$ supplementation probably would not have resulted in an increased forage intake.

The potential degradability (PD) and effective degradability $(\mathrm{ED})$ of the hay did not differ $(p>0.05)$
Table 3 - Rumen $\mathrm{pH}$ among treatments and time-periods of wethers fed Eragrostis curvula hay.

\begin{tabular}{lcccccl}
\hline \multicolumn{7}{c}{ Treatments $^{*}$} \\
\hline Parameters & T0 & T15 & T30 & T45 & T60 & Mean \\
\hline Mean rumen pH & 6.47 & 6.46 & 6.53 & 6.49 & 6.48 & 6.48 \\
Rumen pH/ & & & & & & \\
Time periods & & & & & & \\
00h00 & $6.34^{2}$ & 6.34 & $6.46^{23}$ & $6.40^{2}$ & $6.48^{12}$ & $6.40^{45}$ \\
$03 \mathrm{~h} 00$ & $6.38^{12}$ & 6.34 & $6.44^{23}$ & $6.56^{2}$ & $6.32^{2}$ & $6.37^{5}$ \\
06h00 & $6.52^{12}$ & 6.44 & $6.54^{123}$ & $6.64^{12}$ & $6.40^{2}$ & $6.48^{34}$ \\
09h00 & $6.52^{12}$ & 6.56 & $6.62^{12}$ & $6.52^{12}$ & $6.52^{12}$ & $6.56^{12}$ \\
$12 \mathrm{~h} 00$ & $6.58^{1}$ & 6.56 & $6.74^{1}$ & $6.64^{1}$ & $6.64^{1}$ & $6.63^{1}$ \\
$15 \mathrm{~h} 00$ & $6.46^{12}$ & 6.46 & $6.36^{3}$ & $6.52^{12}$ & $6.50^{12}$ & $6.44^{345}$ \\
$18 \mathrm{~h} 00$ & $6.56^{12}$ & 6.46 & $6.54^{123}$ & $6.44^{12}$ & $6.48^{12}$ & $6.48^{234}$ \\
$21 \mathrm{~h} 00$ & $6.34^{12}$ & 6.48 & $6.52^{123}$ & $6.52^{12}$ & $6.46^{12}$ & $6.51^{23}$ \\
${ }^{*}$ SEM & 0.08 & 0.08 & 0.08 & 0.08 & 0.08 & 0.08
\end{tabular}

No linear, cubic or quadratic effects were observed among treatments in any parameter as the level of urea substituting the RDN (rumen degradable nitrogen) fraction of the SFM to the wethers was increased. The mean rumen $\mathrm{pH}$ did not differ $(p>0.05)$ among treatments. Means within a column with different numerical superscripts ${ }^{1,2,3}$ differ $(p<0.05)$. ${ }^{*}$ T0 (100 \% SFM, $0 \%$ urea); T15 ( $85 \%$ SFM, $15 \%$ urea); T30 (70\% SFM, $30 \%$ urea); T45 (55\% SFM, $45 \%$ urea) and T60 (40\% SFM, $60 \%$ urea); ${ }^{*}$ SEM = Standard error of mean.

between treatments (Table 2). These values are similar to those observed by Flachowsky and Tiroke (1993) on Merino rams consuming wheat straw. The relative high discrepancies observed between PD and ED in the present study (Table 2) could be attributed to the low rates of degradation (c-value, ranging from $1.5 \%$ to $2.0 \%$ between treatments) and low rapid soluble fractions (a-value, ranging from $6 \%$ to $10 \%$ between treatments) observed in the wethers. While ED was not calculated in the study of Flachowsky and Tiroke (1993), similar, but slightly higher rates of degradability (2\%) and rapid soluble fractions (13\%) were observed by the authors which could have resulted in a similar ED in their study compared to this present study. Detmann et al. (2009) observed an increase in ED of low quality Prairie hay in cattle as the RAN concentration was increased from 5 to $8 \mathrm{mg} \mathrm{dL}^{-1}$ rumen fluid. This increase in RAN concentration was associated with an increase in dietary CP percentage of between $5 \%$ and $6 \%$ through $\mathrm{N}$ supplementation. The authors conclusion was that fiber degradation in tropical grasses could be considered a second order process in which it is not only substrate characteristics that determine fiber degradation, but also enzymatic activity from the ruminal microorganisms. The mean RAN concentration observed in the present study was $8.27 \mathrm{mg} \mathrm{dL}^{-1}$ with the only differences $(p<0.05)$ observed between T60 (9.35 $\mathrm{mg} \mathrm{dL}^{-1}$ ) and T30 (7.41 mg $\mathrm{dL}^{-1}$; Table 4). However, as the ED of the forages did not differ between treatments (Table 2), it is doubtful whether higher levels of $\mathrm{N}$ supplementation could have resulted in an increase in ED. Based on this observation, as well as the relative high NDF intake (g NDF $\mathrm{kg}^{-1} \mathrm{BW}$ ) among treatments, it can be argued that the ED of the hay in the present study was maximised or close to maximum.

The $\mathrm{N}$ intake and apparent $\mathrm{N}$ balance of the wethers as influenced by the treatments are shown in Table 
Table 4 - Rumen fermentation parameters and microbial nitrogen supply of sheep fed Eragrostis curvula hay.

\begin{tabular}{|c|c|c|c|c|c|c|}
\hline \multirow{2}{*}{ Parameters } & \multicolumn{5}{|c|}{ Treatments* } & \multirow[b]{2}{*}{$\mathrm{SEM}^{* *}$} \\
\hline & TO & T15 & T30 & T45 & T60 & \\
\hline Total volatile fatty acid (VFA) concentration (mmol dL-1) & 78.5 & 76.0 & 75.3 & 72.1 & 73.7 & 2.39 \\
\hline \multicolumn{7}{|l|}{ VFA (Molar \%) } \\
\hline Acetate & 79.4 & 77.9 & 79.7 & 79.0 & 79.8 & 0.68 \\
\hline Propionate & $14.5^{\mathrm{ab}}$ & $15.3^{a}$ & $14.2^{\mathrm{ab}}$ & $14.5^{\mathrm{ab}}$ & $14.0^{\mathrm{b}}$ & 0.41 \\
\hline Isobutyrate & $0.63^{\mathrm{a}}$ & $0.62^{\mathrm{a}}$ & $0.53^{\text {ab }}$ & $0.55^{\mathrm{ab}}$ & $0.46^{\mathrm{b}}$ & 0.04 \\
\hline Butyrate & $4.71^{\mathrm{b}}$ & $5.73^{a}$ & $5.15^{\mathrm{ab}}$ & $5.51^{\mathrm{ab}}$ & $5.36^{\mathrm{ab}}$ & 0.28 \\
\hline Valerate & $0.57^{\mathrm{a}}$ & $0.51^{\mathrm{ab}}$ & $0.42^{\mathrm{ab}}$ & $0.47^{\mathrm{ab}}$ & $0.39^{b}$ & 0.04 \\
\hline Acetate: Propionate (A:P) & $5.47^{\mathrm{ab}}$ & $5.08^{b}$ & $5.63^{\mathrm{ab}}$ & $5.46^{\mathrm{ab}}$ & $5.69^{a}$ & 0.11 \\
\hline Mean rumen $\mathrm{NH}_{3}-\mathrm{N}\left(\mathrm{mg} \mathrm{dL}^{-1}\right)$ & $7.84^{\mathrm{ab}}$ & $8.16^{\mathrm{ab}}$ & $7.41^{b}$ & $8.60^{a b}$ & $9.35^{\mathrm{a}}$ & 0.56 \\
\hline $\operatorname{MNS}\left(\mathrm{g} \mathrm{N} \mathrm{d}^{-1}\right)^{\star \star *}$ & 14.18 & 16.32 & 14.45 & 14.45 & 15.56 & 1.50 \\
\hline g MNS kg-1 DOMI**** & 20.64 & 23.38 & 20.13 & 20.55 & 23.33 & 2.47 \\
\hline
\end{tabular}

No linear, cubic or quadratic effects were observed among treatments in any parameter as the level of urea substituting the RDN fraction of the SFM to the wethers, was increased. Means within a row with different subscripts ${ }^{a, b}$ differ $(p<0.05)$. ${ }^{*}$ TO (100 \% SFM, $0 \%$ urea); T15 (85 \% SFM, $15 \%$ urea); T30 (70 \% SFM, $30 \%$ urea); T45 (55\% SFM, $45 \%$ urea) and T60 (40 \% SFM, $60 \%$ urea); * *SEM = Standard error of mean; * * MNS = Microbial nitrogen synthesis; ${ }^{* * * *} \mathrm{~g} \mathrm{MNS} \mathrm{kg}^{-1}$ DOMI = g MNS per kg digestible organic matter intake.

Table 5 - Nitrogen intake and balance of sheep consuming Eragrostis curvula hay as affected by the substitution of the rumen degradable nitrogen fraction of sunflower meal with urea.

\begin{tabular}{|c|c|c|c|c|c|c|}
\hline \multirow{2}{*}{ Parameters } & \multicolumn{5}{|c|}{ Treatments* } & \multirow[b]{2}{*}{$\mathrm{SEM}^{* *}$} \\
\hline & TO & T15 & T30 & T45 & T60 & \\
\hline \multicolumn{7}{|l|}{ Intake $\left(g N d^{-1}\right)$} \\
\hline Hay N intake & 4.59 & 4.34 & 4.94 & 4.62 & 4.57 & 0.32 \\
\hline Sunflower meal $\mathrm{N}$ intake & $8.69^{a}$ & $7.39^{b}$ & $6.08^{c}$ & $4.78^{d}$ & $3.47^{e}$ & e \\
\hline Urea N intake & $0^{e}$ & $1.10^{\mathrm{d}}$ & $2.21^{c}$ & $3.30^{\mathrm{b}}$ & $4.40^{\mathrm{a}}$ & - \\
\hline Total RDN intake*** & 11.92 & 11.66 & 12.27 & 11.95 & 11.84 & 0.32 \\
\hline Total N intake*** & 13.28 & 12.83 & 12.67 & 12.70 & 12.40 & 0.32 \\
\hline \multicolumn{7}{|l|}{$N$ excretion $\left(g \mathrm{~g} \mathrm{~d}^{-1}\right)$} \\
\hline Fecal N & 5.97 & 5.94 & 5.95 & 5.18 & 5.10 & 0.39 \\
\hline Urinary N & 0.46 & 0.85 & 0.59 & 0.40 & 0.89 & 0.19 \\
\hline Apparent $\mathrm{N}$ balance $\left(\mathrm{g} \mathrm{d}^{-1}\right)$ & 6.87 & 6.06 & 6.14 & 7.10 & 6.42 & 0.39 \\
\hline Apparent N digestibility (\%) & $47^{\mathrm{b}}$ & $48^{\mathrm{b}}$ & $56^{\mathrm{a}}$ & $52^{\mathrm{ab}}$ & $51^{\mathrm{ab}}$ & 2.01 \\
\hline \multicolumn{7}{|c|}{ 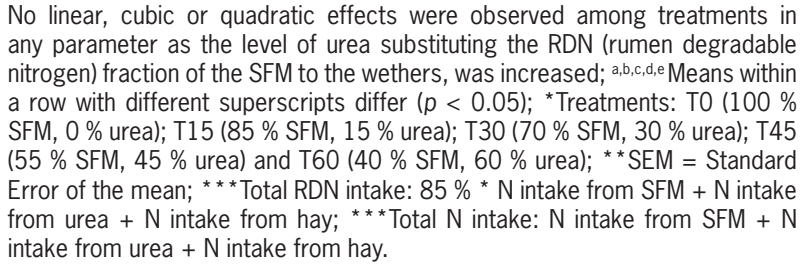 } \\
\hline
\end{tabular}

5. As discussed, the different supplements were formulated to substitute the RDN fractions of the SFM with urea. As a result, RDN intake did not differ between treatments $(p>0.05$; Table 3$)$ as no differences in forage intake were observed between treatments as earlier discussed ( $p>0.05$; Table 2). In a study conducted by Chandrasekharaiah et al. (2012) with sheep fed finger millet straw (C4 grass), it was suggested that $16 \mathrm{~g}$ supplemental RDN kg-1 DOMI might be sufficient for microbial N synthesis and digestibility in sheep fed straw diets. Supplemental RDN intake in the present study was $7.3 \mathrm{~g}$ RDN wether ${ }^{-1} \mathrm{~d}^{-1}$ (Table 5, total RDN intake - hay $\mathrm{N}$ intake).
Using mean DOMI $(0.677 \mathrm{~kg})$ of the wethers among treatments (Table 2) as a basis, mean RDN intake was $10.83 \mathrm{~g}$ RDN kg-1 DOMI. This value is less than the recommendations set by Chandrasekharaiah et al. (2012). While the $\mathrm{N}$ balances of the wethers did not differ across treatments $(p>0.05)$, the mean total apparent $\mathrm{N}$ balance $(6.51 \mathrm{~g} \mathrm{~N}$ wether ${ }^{-1} \mathrm{~d}^{-1}$ ) does suggest that the $\mathrm{N}$ intake of the wethers could have been insufficient to meet their maintenance requirements (NRC, 2007). As the wethers in the present study were supplemented according to NRC (2007) recommendations, this observation highlight the potential difference in $\mathrm{N}$ supplementation requirements between ruminants fed low quality temperate and tropical forages. Rumen $\mathrm{pH}$ as affected by the supplemental treatments is shown in Table 3 . While the rumen $\mathrm{pH}$ did not differ $(p>0.05)$ between treatments, a time-effect was observed with the rumen $\mathrm{pH}$ generally peaking between $09 \mathrm{~h} 00$ and $12 \mathrm{~h} 00$. In contrast, rumen $\mathrm{pH}$ generally was at its lowest level between midnight (00h00) and 03h00 in the morning. These daily rumen $\mathrm{pH}$ patterns correspond with the eating and supplementation patterns of the wethers as they were fed and supplemented at $08 \mathrm{~h} 00$ and at $16 \mathrm{~h} 00$. Results from in sacco degradation studies conducted by Sinclair et al. (1993) suggested that starch disappearance from maize in the rumen might take as long as $5 \mathrm{~h}$ to complete compared to the instantaneous in sacco disappearance of urea. While the rate of degradation of the pure starch was not determined in the present study, the decrease in rumen $\mathrm{pH}$ during the night hours (between $18 \mathrm{~h} 00$ and 06h00) could be indicative of increased starch fermentation during those hours. In addition, rumen fill was possibly at a low during those hours, as most of the feeding would have taken place during the daytime, resulting in less chewing and saliva production that could have buffered the rumen $\mathrm{pH}$. It has to be noted though that the observed differences in rumen $\mathrm{pH}$ among time-periods were biologically insignificant as the values, ranging between 6.32 and 6.74, were well within the range for optimal cellulolytic bacteria fer- 
mentation (Mould and Ørskov, 1983). Rumen pH among all treatments, therefore, was optimal for fiber degradation across all time-periods (Mould and Ørskov, 1983). This was probably due to the supplementation pattern followed during the trial where total daily ingredient supplementation was divided in half and supplemented twice daily at set intervals (08h00 and 16h00).

The VFA profile is typical of a high roughage diet with acetate to propionate $(\mathrm{A}: \mathrm{P})$ ratios ranging between 5.08 and 5.69 (Table 4). Total VFA concentrations did not differ $(p>0.05)$ between treatments. The VFA concentrations, ranging between 72.1 and $78.5 \mathrm{mmol} \mathrm{dL}^{-1}$ among treatments, are similar to the concentrations observed by Fondevila et al. (1994) in sheep fed barley straw. While individual VFA composition differences were observed between treatments $(p<0.05$; Table 4$)$, those differences were inconsistent and biologically insignificant. As a result, the observed differences $(p<0.05)$ in the ratio of acetate: propionate (A: P) between treatments (Table 4) were also biologically insignificant.

Results from various studies suggested that DM intake, MNS and ED in sheep (Kanjanapruthipong and Leng, 1998) and NDF intake, MNS and ED in cattle (Detmann et al., 2009) consuming low quality tropical grasses are influenced by the RAN concentrations, with ED being maximised at $8 \mathrm{mg} \mathrm{NH}_{3}-\mathrm{N} \mathrm{dL}^{-1}$ as was discussed earlier. However, higher RAN concentrations (15 to $20 \mathrm{mg} \mathrm{NH}_{3}-\mathrm{N} \mathrm{dL}^{-1}$ ) were necessary to maximise DMI or NDF intake in cattle (Detmann et al., 2009) and sheep (Kanjanapruthipong and Leng, 1998) consuming low quality tropical forages. The RAN concentration observed in the present study ranged between 7.84 and $9.35 \mathrm{mg} \mathrm{NH}-\mathrm{N} \mathrm{dL}^{-1}$ rumen fluid (Table 4) as was discussed earlier. While it could be argued that these RAN concentrations observed in the present study are below the RAN concentrations suggested by the above mentioned authors (Kanjanapruthipong and Leng. 1998; Detmann et al., 2009), the NDF intake of the wethers among all treatments suggested that forage intake was maximised in the present study (Bohnert et al., 2002; Detmann et al., 2009; Ferrell et al., 1999). It is therefore, doubtful whether higher RAN concentrations, obtained through higher $\mathrm{N}$ supplementation, could have resulted in higher forage intake by the wethers.

Microbial N synthesis and the efficiency of MNS are generally used as parameters to describe the efficiency of microbial fermentation in the rumen (Chen and Gomes, 1992). Leng (1990) suggested that fermentable energy is the nutrient that has the biggest influence on MNS. The MNS in the present study ranged between $14.18 \mathrm{~g}$ and $16.32 \mathrm{~g}$ with no differences observed between treatments. As stated earlier, the supplements were iso-energetic and as such, the lack of differences observed between treatments were expected (Table 4). In a study conducted by Gomes et al. (1994) on sheep fed low quality wheat straw, the highest MNS (18.2 g), using PD as an estimator of MNS, were observed in those sheep where starch was supplemented at $18.6 \%$ of the total diet. The highest starch intake at $50.3 \mathrm{~g}$ starch DM $\mathrm{d}^{-1}$ (Table 1) was supplemented in the T60 treatment, corresponding to a daily starch intake just below $5 \%$ of the total dietary DM intake (Table 2). While the starch supplemented in this treatment only supplied $60 \%$ of the supplemental ME (with the SFM supplying the remainder), the starch levels were significantly less than the maximum levels supplied by Gomes et al. (1994). The possibility therefore does exist that the amount of starch (and total energy intake of the supplements) in the experimental diets of the present study could have been insufficient for maximising MNS.

The efficiency of MNS in the present study, ranging between $20.13 \mathrm{~g} \mathrm{~kg}^{-1}$ DOMI and $23.38 \mathrm{~g} \mathrm{~kg}^{-1}$ DOMI among treatments, was higher compared to the MNS efficiencies observed by Gomes et al. (1994). These higher MNS efficiencies could be indicative that energy supplementation of the wethers among all treatments was sufficient for optimal MNS production. However, as MNS values were lower than the maximum values observed by Gomes et al. (1994), the relative high MNS efficiency values calculated in the present study probably were due to the lower OM digestibility of the diet rather than MNS production per se. It is of interest to note that the MNS efficiency observed in this study is in agreement with the values suggested for ruminants consuming forage based diets (Pathak, 2008). However, based on the low overall digestibility and ruminal degradability of low quality tropical forages, which might have inflated the MNS efficiency values in the present study, it is recommended that total MNS, rather than MNS efficiency, be used as an indicator of microbial efficiency in ruminants consuming low quality tropical forage diets. This observation also emphasises the general wide range (up to 4 times) of MNS efficiencies observed between studies (Chen and Gomes, 1992) as MNS efficiency is not only influenced by factors influencing MNS per se, but also by factors influencing intake and digestibility.

\section{Conclusion}

It is concluded that up to $60 \%$ of the RDN supplied by SFM can be substituted with urea, without affecting intake, digestibility or MNS in wethers receiving low quality E. curvula hay. While ED and forage intake was probably maximised in the present study, total $\mathrm{N}$ balance suggests that RDN supplementation was probably not optimal. It is, therefore, recommended that $\mathrm{N}$ supplementation higher than the current NRC (2007) recommendations has to be adapted to ruminants consuming low quality tropical forages.

\section{References}

Almeida, A.M.; Schwalbach, L.M.; De Waal, H.O.; Greyling, J.P.; Cardoso, L.A. 2006. The effect of supplementation on productive performance of Boer goat bucks fed winter veld hay. Tropical Animal Health Production 38: 443-449. 
Association of Official Analytical Chemists [AOAC]. 2000. Official Method of Analysis. 17ed. Association of Official Analytical Chemists, Rockville, MD, USA.

Arroquy, J.I.; Cochran, R.C.; Wickersham, T.A.; Llewellyn, D.A.; Titgemeyer, E.C.; Nagaraja, T.G.; Johnson, D.E. 2004. Effects of type of supplemental carbohydrate and source of supplemental rumen degradable protein on low quality forage utilization by beef steers. Animal Feed Science and Technology 115: 247-263.

Bohnert, D.W.; DelCurto, T.; Clark, A.A.; Merril, M.L.; Falck, S.J.; Harmon, D.L. 2011. Protein supplementation of ruminants consuming low-quality cool-or warm-season forage: differences in intake and digestibility. Journal of Animal Science 89: 3707-3717.

Bohnert, D.W.; Schauer, C.S.; DelCurto, T. 2002. Influence of rumen protein degradability and supplementation frequency on performance and nitrogen use in ruminants consuming lowquality forage: cow performance and efficiency of nitrogen use in wethers. Journal of Animal Science 80: 1629-1639.

Broderick, G.A.; Kang, J.H. 1980. Automated simultaneous determination of ammonia and total amino acids in ruminal fluid and in vitro media. Journal of Dairy Science 63: 64-75.

Caton, J.S.; Dhuyvetter, D.V. 1997. Influence of energy supplementation on grazing ruminants: requirements and responses. Journal of Animal Science 75: 533-542.

Chandrasekharaiah, M.; Thulasi, A.; Sampath, K.T. 2012. Effect of different rumen degradable nitrogen levels on microbial protein synthesis and digestibility in sheep fed on finger millet straw (Eleucine coracana) based diet. Small Ruminant Research 102: 151-156.

Chen, X.B.; Gomes, M.J. 1992. Estimation of Microbial Protein Supply to Sheep and Cattle Based on Urinary Excretion of Purine Derivatives: An Overview of Technical Details. Rowett Research Institute, Aberdeen, UK. (Technical Report, AB2 9SB).

Cruywagen, C.W. 2006. Technical note: a method to facilitate retrieval of polyester bags used in in sacco trials in ruminants. Journal of Dairy Science 88: 1028-1030.

Detmann, E.; Paulino, M.F.; Mantovani, H.C.; Filho, S.; Sampaio, C.B.; Souza, M.A.; Lazzarini, I.; Detmann, K.S.C. 2009. Parameterization of ruminal fibre degradation in low-quality tropical forage using Michaelis-Menten kinetics. Livestock Science 126: 136-146.

Edjtehadi, M.; Szabuniewics, M.; Emmanuel, D. 1978. Acute urea toxicity in sheep. Canadian Journal of Composite Medicine 42: 63-68.

Engels, E.A.N.; Van der Merwe, F.J. 1967. Application of an in vitro technique to South African forages with special reference to affect certain factors on the results. South African Journal of Agricultural Science 10: 983-995.

Ferrell, C.L.; Kreikemeier, K.K.; Freetly, H.C. 1999. The effect of supplemental energy, nitrogen and protein on feed intake, digestibility and nitrogen flux across the gut and liver in sheep fed low quality forage. Journal of Animal Science 77: 3353-3364.

Flachowsky, G.; Tiroke, K. 1993. Influence of type of feeding and rumen incubation time on in sacco dry matter degradability of ryegrass, straw and concentrate in sheep and goats. Small Ruminant Research 9: 321-330.

Fondevila, M.; Castrillo, C.; Guada, J.A.; Balcells, J. 1994. Effect of ammonia treatment and carbohydrate treatment of barley straw on rumen liquid characteristics and substrate degradation by sheep. Animal Feed Science and Technology 50: 137-155.
Goering, H.K.; Van Soest, P.J. 1988. Forage Fiber Analyses (Apparatus, Reagents, Procedures and some Applications). USDAARS, Washington, DC, USA. (Agriculture Handbook, 379).

Gomes, M.J.; Hovell, F.D.D.B.; Chen, X.B.; Nengomasha, E.M.; Fikremariam, D. 1994. The effect of starch supplementation of straw on microbial protein supply in sheep. Animal Feed Science and Technology 49: 227-286.

Kanjanapruthipong, J.; Leng, R.A. 1998. The effects of dietary urea on microbial populations in the rumen of sheep. American Journal of Animal Science 11: 661-672.

Köster, H.H.; Cochran, R.C.; Titgemeyer, E.C.; Vanzant, E.S.; Abdelgadir, I.; St-Jean, G. 1996. Effect of increasing degradable intake protein on intake and digestion of low-quality, tallgrassprairie forage by beef cows. Journal of Animal Science 74: 24732481.

Köster, H.H.; Cochran, R.C.; Titgemeyer, E.C.; Vanzant, E.S.; Nagaraja, T.G.; Kreikemeier, K.K.; St Jean, G. 1997. Effect of increasing proportion of supplemental nitrogen from urea on intake and utilization of low-quality, tallgrass-prairie forage by beef steers. Journal of Animal Science 75: 1393-1399.

Kozloski, G.V.; Reffatti, M.V.; Bonnecarrère Sanchez, L.M.; Lima, L.D.; Cadorin Jr., R.L.; Härter, C.J.; Fiorentini, G. 2014. Intake and digestion by lambs fed a low-quality grass hay supplemented or not with urea, casein or cassava meal. Animal Feed Science and Technology 136: 191-202.

Leng, R.A. 1990. Factors affecting the utilization of 'poor-quality' forages by ruminants particularly under tropical conditions. Nutrition Research Reviews 3: 277-303.

Mould, F.; Ørskov, E.R. 1983. Manipulation of rumen fluid $\mathrm{pH}$ and its influence on cellulolysis in sacco, dry matter degradation and the rumen microflora of sheep offered either hay or concentrate. Animal Feed Science and Technology 10: 1-14

National Research Council (NRC). 2007. Nutrient Requirements of Small Ruminants: Sheep, Goats, Cervids and New World Camelids. The National Academies Press, Washington, DC, USA.

Ørskov, E.R.; McDonald, I. 1979. The estimation of protein degradability in the rumen from incubation measurements weighted according to rate of passage. Journal of Agricultural Science 92: 499-503.

Pathak, A.K. 2008. Various factors affecting microbial protein synthesis in the rumen. Veterinary World 1: 186-189.

Russel, J.B. 1984. Factors influencing completion and composition of the rumen microbial flora. p. 3351-3561. In: Gilchrist, F.M.C.; Mackie. R.I., eds. Herbivore Nutrition. The Science Press, Craighall, South Africa.

Samuels, M.L. 1989. Statistics for the Life Sciences. Collier MacMillan, London, UK.

Sinclair, L.A.; Garnsworthy, P.C.; Newbold, J.R.; Buttery, P.J. 1993. Effect of synchronizing the rate of dietary energy and nitrogen release on rumen fermentation and microbial protein synthesis in sheep. Journal of Agricultural Science 120: 251-263.

Tilley, J.M.A.; Terry, R.A. 1963. A two stage technique for the in vitro digestion of forage crops. Journal of British Grasslands Society 18: 104-111.

Vanzant, E.S.; Cochran, R.C. 1994. Performance and forage utilization by beef cattle receiving increasing amounts of alfalfa hay as a supplement to low-quality, tallgrass-prairie forage. Journal of Animal Science 72: 1059-1067. 